\title{
Diaphyseal tuberculosis - a rare manifestation
}

\author{
Nitesh Gahlot, ${ }_{1}^{1}$ Uttam Chand Saini, ${ }^{2}$ Devendra Kumar Chouhan ${ }^{2}$
}

${ }^{1}$ Department of Orthopedics, All India Institute of Medical Science, Jodhpur, Rajasthan, India

${ }^{2}$ Department of Orthopedics, Post Graduate Institute of Medical Education and Research, Chandigarh, India

\section{Correspondence to} Dr Uttam Chand Saini doc.uttamsaini@gmail.com

Accepted 6 September 2017

\section{DESCRIPTION}

A 2 year old child presented with low-grade fever, progressive pain and swelling of right leg for the past 3 months. There was no history of injury, chronic cough, respiratory symptoms, weight loss or arthritis. Child's father had been treated for pulmonary tuberculosis 1 year back. On examination, there was a firm, diffuse, tender swelling over the medial aspect of middle one-third of right tibia and matted inguinal lymphadenopathy. Rest of the systemic examination was not contributory. A clinical diagnosis of diaphyseal bone tumour or chronic infective osteomyelitis was considered.

Investigations showed erythrocyte sedimentation rate $46 \mathrm{~mm}$ in first hour, haemoglobin $96 \mathrm{~g} / \mathrm{L}$ and $20 \mathrm{~mm}$ induration after Mantoux test and normal chest radiograph. Radiograph of the right tibia showed a lytic intramedullary bone lesion (Figure 1A-B). MRI confirmed an intramedullary lytic lesion with cortical breach and thickening (figure 1C). Histopathology showed caseous necrosis, granuloma formation, Langhans giant cells and acid-fast bacilli on microscopy and culture. Drug testing could not be done due to the non-availability of this test at that time. He received anti-tubercular therapy for 18 months. Anti-tubercular therapy included 2 months of daily intensive therapy with four drugs: isoniazid (H) $10 \mathrm{mg} / \mathrm{kg}$, rifampicin (R) $15 \mathrm{mg} / \mathrm{kg}$, pyrazinamide (Z) $35 \mathrm{mg} / \mathrm{kg}$ and ethambutol (E) $20 \mathrm{mg} / \mathrm{kg}$. This was followed by 6 months of maintenance therapy with three drugs (HRE) and 10 months of 2 drugs (HR)

\section{Learning points}

- In the absence of specific clinical and radiological signs, a high index of suspicion is needed in children with unexplained pain and swelling of the diaphysis of the bone.

- An osteolytic lesion with sequestrum should be considered infective and tuberculosis should be excluded, especially in endemic regions.

- Clinical and radiological heterogeneity warrant lesional biopsy and culture to establish the correct diagnosis.

in the same daily doses. At 2 years follow-up, the child was well with clinical and radiological resolution of the lesion (figure 1D-F).

Primary diaphyseal tuberculosis is very rare and probably results from hematogenous spread of mycobacteria that remain lodged in the nutrient vessel of the bone and fail to spread to the metaphysis. ${ }^{1}$ Common differential diagnosis include chronic pyogenic or fungal osteomyelitis, Brodie's abscess, bone cysts, tumours or granulomas. ${ }^{2}$ Absence of systemic signs, specific radiographic features and low index of suspicion may delay the diagnosis of tuberculosis. Because of such varied clinical and radiological presentations in endemic areas, biopsy and culture are necessary to establish the diagnosis.

Contributors All authors contributed in preparation of manuscript. NG collected all photographs and kept follow up of patient. US prepared the manuscript. DKC did the final editing.

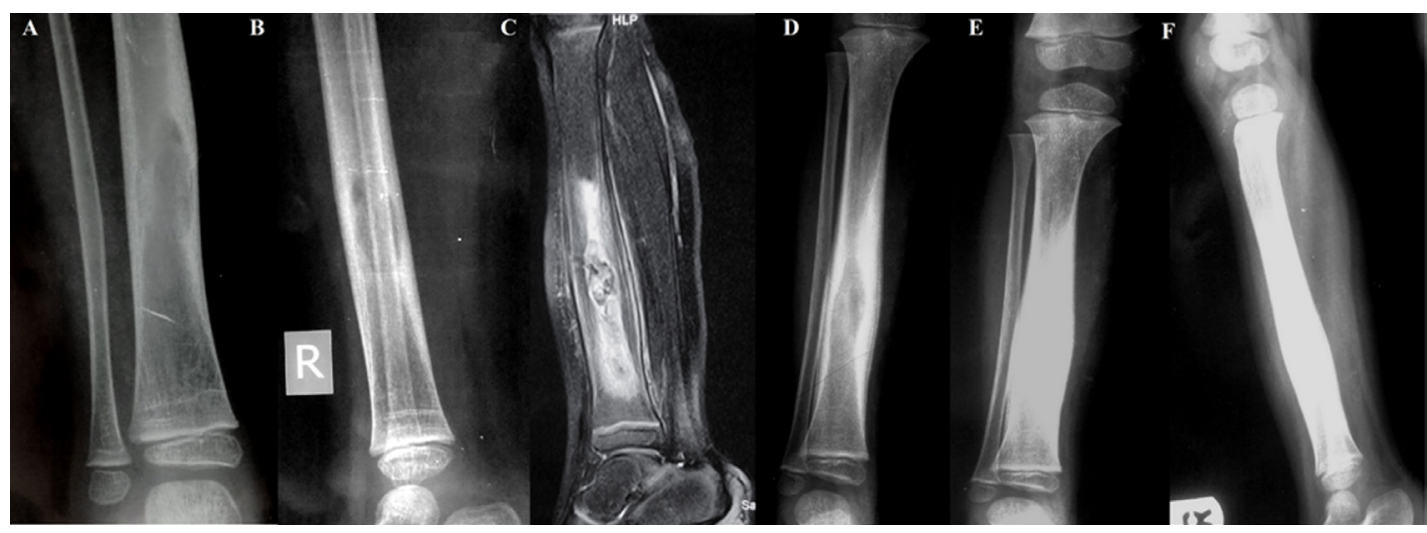

To cite: Gahlot N, Saini UC, Chouhan DK. BMJ Case Rep Published Online First: [please include Day Month Year]. doi:10.1136/bcr-2017221617
Figure 1 (A) Anteroposterior and (B) lateral view radiographs of the right tibia showing a large radiolucent area in the diaphysis (arrow) suggestive of a lytic intramedullary bone lesion extending into the endosteal surface of medial cortex (C) MRI T2-weighted sagittal section of right tibia showing a circumscribed, heterogeneous, necrotic area in the medullary canal with surrounding oedema and cortical sequestrum. The overlying cortex is thickened due to endosteal new bone formation with cortical breach (arrow) and mild swelling of the overlying soft tissue. (D) Anteroposterior radiograph of the right tibia after 1 year of treatment showing cortical thickening and sclerosis indicative of ongoing healing (E) Anteroposterior and (F) lateral view radiographs at 2 years follow-up showing marked sclerosis and healing of lesion. 
Competing interests None declared.

Patient consent Guardian consent obtained.

Provenance and peer review Not commissioned; externally peer reviewed.

(c) BMJ Publishing Group Ltd (unless otherwise stated in the text of the article) 2017. All rights reserved. No commercial use is permitted unless otherwise expressly granted.

\section{REFERENCES}

1 Abdelwahab IF, Bianchi S, Martinoli C, et al. Atypical extraspinal tuberculosis in immunocompetent patients, a review. Part 1: atypical osteoarticular tuberculosis and tuberculous osteomyelitis. Can Assoc Radiol J 2006; 57:86-94.

2 Mathew K, Paulose S, Jose TM. Tuberculosis of proximal Tibia. Kerala Journal of Orthopaedics 2013;26:51-2.

Copyright 2017 BMJ Publishing Group. All rights reserved. For permission to reuse any of this content visit http://group.bmj.com/group/rights-licensing/permissions.

BMJ Case Report Fellows may re-use this article for personal use and teaching without any further permission.

Become a Fellow of BMJ Case Reports today and you can:

- Submit as many cases as you like

- Enjoy fast sympathetic peer review and rapid publication of accepted articles

Access all the published articles

Re-use any of the published material for personal use and teaching without further permission

For information on Institutional Fellowships contact consortiasales@bmjgroup.com

Visit casereports.bmj.com for more articles like this and to become a Fellow 